\title{
Badania nad przestrzeniami organizacji ${ }^{1}$
}

\author{
Dr hab. Piotr Pachura, prof. PC iD \\ Politechnika Częstochowska, Wydział Zarządzania \\ Katedra Informatyki Ekonomicznej i Ekosystemów Zarządzania
}

\section{Wprowadzenie}

Przestrzeń fascynowała myślicieli od początków rozwoju cywilizacji. Zajmowali się nią najwybitniejsi filozofowie, począwszy od starożytności, oraz kluczowi przedstawiciele nauk przyrodniczych. Przestrzeń - i jej zrozumienie w postaci języka matematyki - stanowiła domenę geometrów, kosmologów i fizyków. Nauki społeczno-ekonomiczne, $\mathrm{w}$ dużym uproszczeniu, nie uznawały przestrzeni za zbyt inspirującą kategorię poznawczą. Być może dlatego, że przez wiele stuleci dominowało absolutystyczne podejście do istnienia przestrzeni. Konsekwencją pojęcia przestrzeni absolutnej jest uznanie jej istnienia niezależnie od materii i czasu ${ }^{2}$. W tym podejściu uznawano przestrzeń za byt „pusty”, czyli zbiornik lub kontener, w którego wnętrzu rozgrywają się zdarzenia i umiejscowione są obiekty materialne. Interesujące były zdarzenia i obiekty, a nie sam „pojemnik”. W przypadku badań w naukach ekonomicznych przestrzeń była głównie odległością, dystansem lub lokalizacją. Kluczowe znaczenie w pierwszych teoriach lokalizacji miał czynnik przestrzeni w sensie odległości geograficznej, odległości od surowców, rynków zbytu, infrastruktury czy też zasobów ludzkich. W pierwszych teoriach lokalizacji najważniejszymi kryteriami były: koszty transportu, koszty pracy czy korzyści aglomeracji ${ }^{3}$. Współcześnie przestrzeń ma dla przedsiębiorstw wymiar globalny i lokalny, gdyż jednym z bardzo ważnych zjawisk w praktykach organizacji jest wykorzystywanie lokalności czy eksploracji lokalnych zasobów oraz zakorzenienia w miejscu fizycznej lokalizacji z równoczesną penetracją sfery globalnej4.

1 Badania zaprezentowane w opracowaniu są częścią projektu badawczego nr 2017/25/B/ HS4/01007 pt. „Przestrzeń w organizacji - organizacja w przestrzeni. Hipoteza teorii przestrzeni” finansowanego ze środków Narodowego Centrum Nauki w ramach konkursu „OPUS $13 "$.

2 I. Newton, Matematyczne zasady filozofii przyrody, Copernicus Center Press, Kraków 2011.

3 A. Weber, The Theory of the Location of Industries, Chicago University Press, Chicago 1929.

4 S. Yip, Strategia globalna, Polskie Wydawnictwo Ekonomiczne, Warszawa 2004. 
W przypadku nauk o zarządzaniu ugruntowała się perspektywa interpretacji dwóch rodzajów przestrzeni: wewnątrzorganizacyjnej i otoczenia organizacji. Pomiędzy nimi znajduje się granica organizacji rozumiana fizycznie, formalnie czy też metaforycznie. Granice organizacji mają znaczenie dla całego kompleksu uwarunkowań strategicznych. Formułując znaną definicję strategii, iż jest to sposób reakcji organizacji na jej otoczenie, dostrzegamy wyraźnie tę dychotomię, polegającą na postrzeganiu przestrzeni wewnętrznej organizacji oraz otaczającej jako dwóch niezależnych, autonomicznych bytów. Te dwie przestrzenie pozostają w ciągłym napięciu i konflikcie, z drugiej strony poszukując stanu równowagi. Wzrastające uzależnienie organizacji od przestrzeni wirtualnych, przy jednoczesnym osadzeniu wszelkich działań w przestrzennym kontekście miejsca, stwarza nowe wyzwania dla nauk o organizacji i procesach zarządzania. Celem niniejszego opracowania jest prezentacja wstępnych doniesień z badań nad przestrzeniami organizacji na podstawie przyjętego modelu teoretycznego, z zastosowaniem technik ilościowych.

\section{Propozycja modelu teoretycznego}

Punktem wyjścia dla prac naukowych opisanych w niniejszym tekście była propozycja autorskiego modelu czterech wymiarów przestrzeni dla współczesnych organizacji (model a priori). Propozycja modelu (rysunek 1) zakładała występowanie następujących przestrzeni:

1) przestrzeni organizacji,

2) przestrzeni glokalnej (rozpiętej jako kontinuum pomiędzy lokalnością a globalnością),

3) przestrzeni topicznej (kontekstowej) oraz

4) cyberprzestrzeni (przestrzeni wirtualnej).

Model ten (rysunek 1) stanowił podstawę do realizacji postawionego celu badawczego, polegającego na jego eksperymentalnej weryfikacji w kierunku identyfikacji występowania, konfiguracji oraz znaczenia wielowymiarowych przestrzeni współczesnych organizacji.

Model teoretyczny (a priori) przedstawiony na rysunku 1 powstał w wyniku interdyscyplinarnych studiów teoretycznych. Badania obejmowały dorobek oraz koncepcje dotyczące ontologii i epistemologii przestrzeni w perspektywach wielu podejść i dyscyplin naukowych, takich jak filozofia, socjologia, fizyka, geometria, ekonomia, nauki o organizacji i zarządzaniu, i były prowadzone w latach 2015-20195.

5 P. Pachura, O przestrzeni w zarzqdzaniu. Studium metodologiczne, Wydawnictwo Naukowe PWN, Warszawa 2016. 


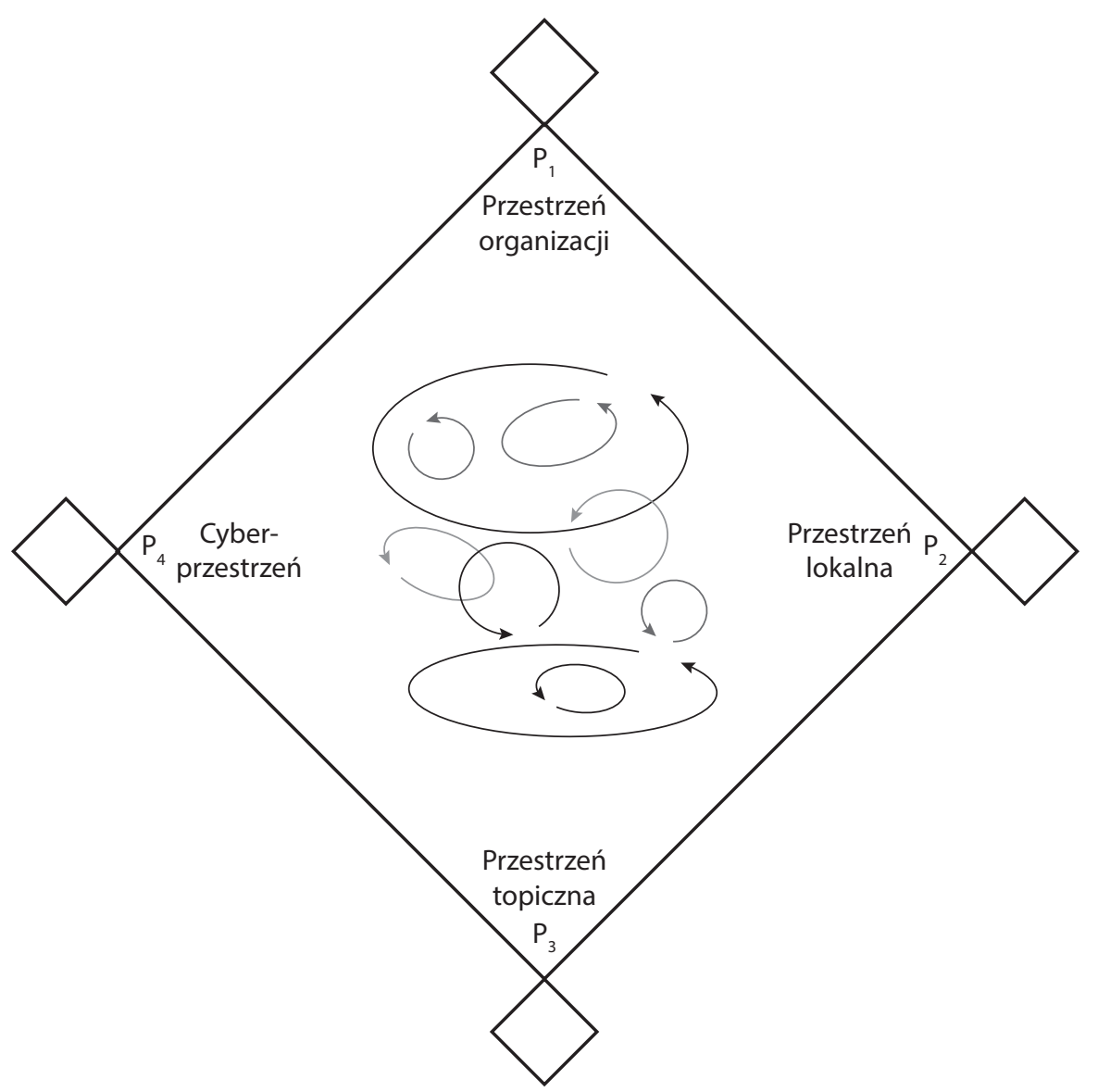

Rysunek 1. Teoretyczny model czterech wymiarów przestrzeni organizacji

Źródto: P. Pachura, O przestrzeni w zarzq̨dzaniu. Studium metodologiczne, Wydawnictwo Naukowe PWN, Warszawa 2016, s. 87.

\section{Metodologia badań}

Przyjęcie zaprezentowanego powyżej modelu oparte było na badaniach teoretycznych. Aby móc odnieść model do rzeczywistości, należy przyjąć procedurę weryfikacyjną bazującą na podejściu empirycznym. Przyjęta procedura badawcza zakładała triangulację metodologiczną ${ }^{6}$. Pierwsza faza badań objęła analizę źródeł wtórnych oraz konceptualizacje problemu przy zastosowaniu metody panelu

6 Triangulacja to świadomy, podejmowany już na etapie projektowania badania przez badacza zabieg, umożliwiający realizację następujących celów ogólnych: krzyżową, wzajemną weryfikację rezultatów badawczych uzyskiwanych w ramach poszczególnych technik 
eksperckiego. Zasadniczy cel tego etapu stanowiło poznanie zakresu, treści i wymiarów przestrzeni organizacji oraz konceptualna weryfikacja modelu teoretycznego. Efektem było opracowanie kluczowego dla całego procesu pomiaru sposobu rozumienia przestrzeni, stanowiącego syntezę naukowego i potocznego sposobu jego percepcji. Rezultatem tej części procedury było skonstruowanie narzędzi zastosowanych na etapie badania empirycznego. Na główną część pomiaru złożyło się badanie ilościowe i dwa jakościowe, wzajemnie ze sobą powiązane. W pierwszej kolejności zrealizowano pomiar jakościowy metodą indywidualnych wywiadów pogłębionych wśród kadry menedżerskiej, w celu weryfikacji podejścia metodycznego, a także pogłębienia rozumienia zjawiska ${ }^{7}$. Badania ogniskujące się na poznaniu empirycznym najczęściej wykorzystują ilościowe narzędzia, przy zastosowaniu metody kwestionariuszowej lub ankietowej, poddając pomiarowi ogólnokrajowe próby populacji generalnej. Informacje o badanej populacji pod względem rozkładu geograficznego zaprezentowano w tabeli 1.

Tabela 1. Podział badanej populacji ze względu na region NUTS $(N=406)$

\begin{tabular}{|l|r|r|}
\hline \multirow{2}{*}{ Klasyfikacja NUTS } & \multicolumn{2}{c|}{ Wskazania respondentów } \\
\cline { 2 - 3 } & $N$ & $\%$ \\
\hline Region pótnocny & 56 & 13,8 \\
\hline Region pótnocno-zachodni & 63 & 15,5 \\
\hline Region centralny & 115 & 28,3 \\
\hline Region południowo-zachodni & 39 & 9,6 \\
\hline Region południowy & 86 & 21,2 \\
\hline Region wschodni & 47 & 11,6 \\
\hline Razem & $\mathbf{4 0 6}$ & $\mathbf{1 0 0 , 0}$ \\
\hline
\end{tabular}

Źródło: opracowanie wtasne.

Tabela 2. Podział badanej populacji ze względu na branżę $(N=406)$

\begin{tabular}{|l|c|c|}
\hline \multirow{2}{*}{ Branża działalności } & \multicolumn{2}{|c|}{ Wskazania respondentów } \\
\cline { 2 - 3 } & $N$ & $\%$ \\
\hline Produkcja & 177 & 43,6 \\
\hline Handel & 102 & 25,1 \\
\hline Usługi & 79 & 19,5 \\
\hline Administracja & 48 & 11,8 \\
\hline
\end{tabular}

Źródto: opracowanie własne.

pomiaru, wielowymiarowość oglądu problemu badawczego oraz pogłębienie wiedzy na temat przedmiotu badań.

7 Niniejszy tekst obejmuje w dalszej części prezentację wyników badania ilościowego. Rezultaty badań jakościowych zostały pominięte ze względu na objętość opracowania. 
W celu zapewnienia reprezentatywności próby badanie obejmowało różne branże - największy odsetek stanowiła branża produkcyjna. Podział badanej populacji ze względu na branże przedstawia tabela 2. Największy zakres postępowania badawczego w opisywanej procedurze stanowiło zatem przeprowadzenie wywiadów telefonicznych wspomaganych komputerowo na ogólnopolskiej próbie przedsiębiorstw, którego celem było ustalenie częstości występowania w populacji poszczególnych typów empirycznych postaw i rozumienia przestrzeni wśród kadry menedżerskiej.

\section{Wyniki badań ilościowych}

Badania ilościowe zostały przeprowadzone metodą indywidualnych wywiadów pogłębionych wśród kadry menedżerskiej 406 przedsiębiorstw. Ponieważ badane zagadnienie mogło stanowić duże wyzwanie dla respondentów ${ }^{8}$, przygotowanie narzędzia wymagało bardzo starannego zaprojektowania. Kwestionariusz wywiadu zawierał 64 pytania ${ }^{9}$, występowały pytania otwarte, zamknięte oraz pytania zawierające zdania metaforyczne i kontrfaktyczne. Pytania zostały uszeregowane zgodnie z kategoriami, subaspektami przestrzeni zobrazowanymi na rysunku 1 , czyli (1) przestrzeń organizacji ${ }^{10}$, (2) przestrzeń glokalna (rozpięta jako kontinuum pomiędzy lokalnością a globalnością), (3) przestrzeń topiczna (kontekstowa) oraz (4) cyberprzestrzeń (przestrzeń wirtualna). Tabele 1-4 przedstawiają wstępne, wybrane interpretacje wyników w poszczególnych kategoriach przestrzeni w odniesieniu do analiz statystycznych.

Uzyskane wyniki stanowić będą bazę empiryczną dla weryfikacji modelu teoretycznego przestrzeni organizacji. Weryfikacja modelu w kierunku budowy modelu a posteriori ujawniła, że przestrzeń organizacji dla kadry menedżerskiej egzystuje w świadomości głównie w trzech aspektach:

1) istotności i niezbędności przestrzeni wewnętrznej organizacji, w tym przestrzeni osobistej miejsca pracy oraz przestrzeni lokalnej poza granicami organizacji;

2) istotności i niezbędności układów i relacji sieciowych z podmiotami zewnętrznymi (głównie lokalnymi) z niewielkim występowaniem w percepcji elementów symbolicznych i metaforycznych;

$8 \quad$ Z założenia niedostrzegających aspektów przestrzeni w działalności organizacji.

9 Bez pytań metryczkowych.

10 Poszczególne kategorie, subaspekty przestrzeni zostały dodatkowo podzielone na trzy składowe dla każdego wymiaru przestrzeni, czyli na przykład dla (1) przestrzeni organizacji na: przestrzeń wewnętrzna organizacji, przestrzeń zewnętrzna (otoczenie organizacji), struktury organizacyjne. W niniejszym opracowaniu pominięto szczegółowy opis struktury narzędzia. 
3) poziomu wystarczalności i konieczności modernizacji i dostosowania dla użytkowników przestrzeni wewnętrznej organizacji na poziomie makro (budynki) i mikro (miejsce pracy).

Tabela 3. Aspekt przestrzeni fizycznej: weryfikacja modelu teoretycznego - analiza ilościowa metodami statystyki opisowej i indukcyjnej

\begin{tabular}{|c|c|c|c|}
\hline \multirow[b]{2}{*}{$\begin{array}{l}\text { Wymiary } \\
\text { modelu }\end{array}$} & \multicolumn{2}{|c|}{ Analiza ilościowa metodami statystyki opisowej } & \multirow{2}{*}{$\begin{array}{c}\text { Analiza ilościowa } \\
\text { metodami statystyki } \\
\text { indukcyjnej modelu } \\
\text { a priori }\end{array}$} \\
\hline & $\begin{array}{l}\text { Miary tendencji } \\
\text { centralnej }\end{array}$ & Miary dyspersji & \\
\hline $\begin{array}{l}\text { Przestrzeń } \\
\text { fizyczna }\end{array}$ & $\begin{array}{l}\text { Najmniejszą istotność } \\
\text { w przypadku tego } \\
\text { aspektu wykazata } \\
\text { analiza przestrzeni } \\
\text { formalnej i nieformalnej. } \\
\text { Najważniejsze } \\
\text { dla respondenta } \\
\text { są: wizerunek } \\
\text { organizacji, hierarchia } \\
\text { przedsiębiorstwa oraz } \\
\text { wewnętrzna przestrzeń } \\
\text { komunikacyjna. }\end{array}$ & $\begin{array}{l}\text { Do najbardziej } \\
\text { różnicujących aspektów } \\
\text { po względem świadomości } \\
\text { należą: fizyczna przestrzeń } \\
\text { wewnętrzna organizacji, } \\
\text { przestrzeń formalna, } \\
\text { zewnętrzna struktura } \\
\text { organizacji. Aspektami } \\
\text { różniącymi się w opinii } \\
\text { badanych, do których } \\
\text { przywiązują oni najwyższą } \\
\text { wagę, są formalna } \\
\text { i nieformalna przestrzeń } \\
\text { organizacji. }\end{array}$ & $\begin{array}{l}\text { Zaobserwowano } \\
\text { istotne różnice } \\
\text { w zależności od wielkości } \\
\text { zatrudnienia. Największe } \\
\text { różnice obserwowane } \\
\text { są w przestrzeni } \\
\text { nieformalnej organizacji. } \\
\text { Pozostałe subaspekty } \\
\text { - przestrzeni fizycznej } \\
\text { nie wyróżniają się } \\
\text { w większym stopniu. }\end{array}$ \\
\hline
\end{tabular}

Źródło: opracowanie własne.

Tabela 4. Aspekt przestrzeni glokalnej: weryfikacja modelu teoretycznego - analiza ilościowa metodami statystyki opisowej i indukcyjnej

\begin{tabular}{|c|c|c|c|}
\hline \multirow{2}{*}{$\begin{array}{l}\text { Wymiary } \\
\text { modelu }\end{array}$} & \multicolumn{2}{|c|}{ Analiza ilościowa metodami statystyki opisowej } & \multirow{2}{*}{$\begin{array}{l}\text { Analiza ilościowa } \\
\text { metodami statystyki } \\
\text { indukcyjnej a priori }\end{array}$} \\
\hline & $\begin{array}{l}\text { Miary tendencji } \\
\text { centralnej }\end{array}$ & Miary dyspersji & \\
\hline $\begin{array}{l}\text { Przestrzeń } \\
\text { globalna/ } \\
\text { lokalna }\end{array}$ & $\begin{array}{l}\text { Zaobserwowano } \\
\text { dominującą tendencję } \\
\text { do występowania } \\
\text { struktur sieciowych } \\
\text { w przestrzeni glokalnej. } \\
\text { Przedsiębiorstwa } \\
\text { najczęściej nawiązują } \\
\text { współpracę poprzez } \\
\text { układy sieciowe. }\end{array}$ & $\begin{array}{l}\text { Największe różnice } \\
\text { w udzielanych } \\
\text { odpowiedziach występują } \\
\text { w przypadku określenia } \\
\text { przedsiębiorstwa mianem } \\
\text { globalnego. Najczęściej } \\
\text { menedżerowie nie } \\
\text { umiejscawiają organizacji } \\
\text { w polu globalnym, a raczej } \\
\text { lokalnym czy krajowym lub } \\
\text { międzynarodowym. }\end{array}$ & $\begin{array}{l}\text { Ten aspekt przestrzeni } \\
\text { jest raczej istotny, lecz } \\
\text { - co ciekawe - podlega } \\
\text { percepcji w dużej } \\
\text { mierze w kategoriach } \\
\text { symbolicznych lub } \\
\text { metaforycznych. }\end{array}$ \\
\hline
\end{tabular}

Źródło: opracowanie własne. 
Tabela 5. Aspekt przestrzeni kontekstu: weryfikacja modelu teoretycznego - analiza ilościowa metodami statystyki opisowej i indukcyjnej

\begin{tabular}{|c|c|c|c|}
\hline \multirow{2}{*}{$\begin{array}{l}\text { Wymiary } \\
\text { modelu }\end{array}$} & \multicolumn{2}{|c|}{ Analiza ilościowa metodami statystyki opisowej } & \multirow{2}{*}{$\begin{array}{c}\text { Analiza ilościowa } \\
\text { metodami statystyki } \\
\text { indukcyjnej a priori }\end{array}$} \\
\hline & $\begin{array}{l}\text { Miary tendencji } \\
\text { centralnej }\end{array}$ & Miary dyspersji & \\
\hline $\begin{array}{l}\text { Przestrzeń } \\
\text { kontekstu }\end{array}$ & $\begin{array}{l}\text { Nie ma istotnych różnic, } \\
\text { które podlegałyby } \\
\text { analizie statystycznej. }\end{array}$ & $\begin{array}{l}\text { Największe różnice } \\
\text { w analizie przedsiębiorstw } \\
\text { występują w ocenie } \\
\text { kobiet i mężczyzn w nim } \\
\text { pracujących oraz w liczbie } \\
\text { budynków należących } \\
\text { do przedsiębiorstwa i liczbie } \\
\text { kondygnacji. }\end{array}$ & $\begin{array}{l}\text { Przestrzeń kontekstu } \\
\text { nie jest wyraźnie } \\
\text { obserwowana } \\
\text { we wskazaniach kadry } \\
\text { menedżerskiej. }\end{array}$ \\
\hline
\end{tabular}

Źródło: opracowanie własne.

Tabela 6. .Aspekt cyberprzestrzeni: weryfikacja modelu teoretycznego - analiza ilościowa metodami statystyki opisowej i indukcyjnej

\begin{tabular}{|c|c|c|c|}
\hline \multirow{2}{*}{$\begin{array}{l}\text { Wymiary } \\
\text { modelu }\end{array}$} & \multicolumn{2}{|c|}{$\begin{array}{c}\text { Analiza ilościowa metodami statystyki } \\
\text { opisowej }\end{array}$} & \multirow{2}{*}{$\begin{array}{l}\text { Analiza ilościowa metodami statystyki } \\
\text { indukcyjnej a priori }\end{array}$} \\
\hline & $\begin{array}{l}\text { Miary tendencji } \\
\text { centralnej }\end{array}$ & Miary dyspersji & \\
\hline $\begin{array}{l}\text { Cyber- } \\
\text { przestrzeń }\end{array}$ & $\begin{array}{l}\text { Kategoria przestrzeni } \\
\text { bardzo istotna. } \\
\text { Potencjalne pole } \\
\text { do dalszej eksploracji. }\end{array}$ & $\begin{array}{l}\text { Wskazania } \\
\text { bardzo } \\
\text { zróżnicowane, } \\
\text { brak jasnych } \\
\text { zależności. }\end{array}$ & $\begin{array}{l}\text { Najistotniejsze różnice w przypadku } \\
\text { tej kategorii przestrzeni obserwowane } \\
\text { są w podziale na wielkość zatrudnienia, } \\
\text { mniej istotne w podziale na branże, brak } \\
\text { istotności w pozostałych przypadkach. }\end{array}$ \\
\hline
\end{tabular}

Źródto: opracowanie własne.

Z badań wynika również, iż zasadniczymi wymiarami przestrzeni są elementy silnie funkcjonalne, które można sklasyfikować wokół takich aspektów jak (A) lokalność, (B) sieciowość, (C) materialność i (D) pragmatyzm.

Lokalność (A) ujawniła się poprzez bardzo silne zogniskowanie percepcji na najbliższym otoczeniu. Istotne znaczenie ma tu ujawnione w pierwszym aspekcie głównym, czyli przestrzeni fizycznej, posiadanie własnego miejsca pracy w postaci wydzielonej przestrzeni biura. Znamienne jest również postrzeganie rzeczywistości organizacyjnej przede wszystkim w kategoriach konkretnych budynków i biur firmy.

Istotność aspektu sieciowości (B) można uznać za pewne odkrycie ${ }^{11}$, gdyż w przypadku przedmiotowych badań postrzeganie przestrzeni organizacyjnej dotyczyło przestrzenności sieci relacji i ich zakorzenienia w przestrzeni. Perspektywa

11 Pomimo innych, wcześniejszych, ważnych badań nad sieciowością - zarówno krajowych, jak i zagranicznych. 
sieciowych relacji przestrzennych odnosi się zarówno do elementów inkorporowanych, takich jak współczesne filie i franczyzy, jak i do ważnego znaczenia podmiotów zewnętrznych: podwykonawców, sieci biznesowych i organizacyjnych, lokalnego biznesu i instytucji. Jednocześnie można też dostrzec silne elementy symboliczne, ujawniające się poprzez podkreślanie przez menedżerów aspektów kultury organizacyjnej oraz pewnych elementów reprezentacyjnych, służących komunikacji, na przykład sal konferencyjnych.

Ciekawym wynikiem badań okazuje się ujawnienie, iż percepcja przestrzeni przez menedżerów występuje głównie w kategoriach materialnych (C) i pragmatycznych (D). Doświadczanie i myślenie o przestrzeni ogniskują się na przestrzeni fizycznej, skonstruowanej czy też postrzeganej jako konfiguracja przestrzenna obiektów materialnych ${ }^{12}$. Warto też zwrócić uwagę na fakt, iż badani w tym zakresie postrzegają przestrzeń organizacyjną w kategoriach interesów swojej firmy. Pragmatyzm ten został również ujawniony poprzez koncentrację na tym, co niezbędne do działania w sensie praktycznym i materialnym, przy jednoczesnym silnym myśleniu oceniającym. Menedżerowie w organizacji, interpretując jej przestrzenie, formują swoje myśli w kategoriach tego, co dla organizacji (i dla nich w organizacji) istotne, niezbędne, wystarczalne lub wymagające usprawnień i modyfikacji.

\section{Dyskusja}

Problematyka badań nad przestrzenią nie jest najczęściej głównym obszarem analizy w polskiej i zagranicznej tradycji akademickiej związanej z naukami o zarządzaniu. Podobnie jak w naukach przyrodniczych, gdzie przez długi czas dominowało podejście absolutystyczne, tak i w naukach o zarządzaniu obowiązywał paradygmat „organizacja - otoczenie” jako główna perspektywa interpretacyjna. Jeden z pierwszych całościowych programów badawczych dotyczących (w pewnym sensie) przestrzeni stanowi dorobek związany $\mathrm{z}$ badaniami nad granicami organizacji ${ }^{13}$. Na uwagę zasługują również badania w nurcie zarządzania strategicznego w kontekście lokalizacji przestrzennej przedsiębiorstw i wpływu zewnętrznego

12 Nawiązując do ontologii przestrzeni w różnych tradycjach naukowych, można to odnieść do istnienia przestrzeni relacyjnej, czyli jej percepcji kształtowanej poprzez umiejscowienie obiektów i relacji pomiędzy nimi. Takie podejście zauważamy w pracach Leibniza, który być może jako pierwszy przeciwstawiał się absolutystycznemu rozumieniu przestrzeni - zob. J. Czerniawski, Czasoprzestrzeń Leibniza w fizyce nierelatywistycznej i w teorii względności, „Przegląd Filozoficzny” 2017, t. 26, nr 1, s. 33-52.

13 S. Cyfert, Granice organizacji, Wydawnictwo Uniwersytetu Ekonomicznego w Poznaniu, Poznań 2012; R. Romanowska, Granice organizacji, [w:] M. Romanowska, J. Cygler (red.), Granice zarządzania, Oficyna Wydawnicza SGH - Szkoła Główna Handlowa w Warszawie, Warszawa 
środowiska na funkcjonowanie organizacji14. Warto także wspomnieć o przykładach konceptualizacji ontologii przestrzeni w nielicznych pracach o tej tematyce w nurcie nauk o zarządzaniu ${ }^{15}$. W świetle wstępnej prezentacji wyników badań przedstawionych w niniejszym opracowaniu, a dotyczących znaczenia przestrzeni w kontekście sieci relacji, warto odwołać się do wcześniejszych prac potwierdzających znaczenie tej problematyki ${ }^{16}$. Podkreślić trzeba na przykład dorobek badań nad problematyką funkcjonowania i zarządzania klastrami ${ }^{17}$ jako przestrzennymi sieciami współpracy ${ }^{18}$. Należy wskazać na dobrze rozwinięty stan analiz w zakresie zagadnień kontekstowych przejawiających się w badaniach nad kulturą organizacyjną ${ }^{19}$. W ostatnich latach w Polsce i na świecie rozwinęły się badania nad wirtualnością działalności przedsiębiorstw, zapoczątkowane koncepcjami modeli e-biznesu ${ }^{20}$. Badania w poszczególnych obszarach - aspektach modelu teoretycznego przestrzeni (rysunek 1: przestrzeń fizyczna, glokalna, kontekstowa i cyberprzestrzeń) pozwalają zatem na ugruntowanie podejścia teoretycznego.

2014; S. Cyfert, Mechanizmy zarzqdzania granicami - propozycja teoretycznego ujęcia i wyniki badań empirycznych, „Współczesne Zarządzanie” 2012, nr 3, s. 17-24.

14 M. Romanowska, Alianse strategiczne przedsiębiorstw, Polskie Wydawnictwo Ekonomiczne, Warszawa 1997; G. Gierszewska, M. Romanowska, Analiza strategiczna przedsiębiorstwa, Polskie Wydawnictwo Ekonomiczne, Warszawa 1994; G. Gierszewska, B. Wawrzyniak, Globalizacja, wyzwania dla zarzq̨dzania strategicznego, Poltext, Warszawa 2001; A. Zaorska, Ku globalizacji? Przemiany w korporacjach transnarodowych i w gospodarce światowej, Wydawnictwo Naukowe PWN, Warszawa 1998; A. Koźmiński, Zarzq̨dzanie międzynarodowe, Polskie Wydawnictwo Ekonomiczne, Warszawa 1999.

15 Na przykład K. Perechuda, Filozofia pustki, struktury-symulakry. Rozważania w kontekście koncepcji Profesora Adama Stabryły, [w:] H. Bieniok (red.), Wspótczesne kierunki rozwoju nauk o zarzqdzaniu w kontekście dokonań naukowych Profesora Adama Stabryły, Mfiles.pl, 2014; P. Pachura, O przestrzeni...

16 Por. W Czakon, Sieci w zarzqdzaniu strategicznym, Wolters Kluwer Polska, Warszawa 2012; K. Perechuda, Dyfuzja wiedzy w przedsiębiorstwie sieciowym. Wizualizacja i kompozycja, Wydawnictwo Akademii Ekonomicznej, Wrocław 2005; W. Czakon, Hipoteza bliskości, „Przegląd Organizacji” 2010, nr 9.

17 Niedoceniany w pierwszym okresie rozwoju w Polsce.

18 Na przykład M. Gorynia, B. Jankowska, Klastry a międzynarodowa konkurencyjność i internacjonalizacja przedsiębiorstwa, Wydawnictwo Difin, Warszawa 2008; L. Knop i wsp., Modele zarządzania klastrami. Wybrane przykłady, Wydawnictwo Politechniki Śląskiej, Gliwice 2013; E. Bojar, Z. Olesiński, The emergence and development of clusters in Poland, Wydawnictwo Difin, Warszawa 2007.

19 Na przykład B. Nogalski, Kultura organizacyjna. Duch organizacji, Oficyna Wydawnicza Ośrodka Postępu Organizacyjnego, Bydgoszcz 1998; Ł. Sułkowski, Procesy kulturowe w organizacjach, Towarzystwo Naukowe Organizacji i Kierownictwa „Dom Organizatora”, Toruń 2002.

20 Na przykład J. Brzózka, D. Jelonek, Koncepcja pomiaru wartości tworzonej przez aplikacje modeli biznesu: podstawy teoretyczne i studium przypadku, „Przegląd Organizacji” 2015, nr 9; J. Wielki, Analiza rozwoju modeli biznesowych opartych na wykorzystaniu Internetu, „Problemy Zarządzania. Zeszyt Specjalny” 2011. 
Jednocześnie należy zauważyć, iż zaproponowany model a priori pozwala prawdopodobnie na całościowe ujęcie i holistyczną analizę poszczególnych aspektów przestrzeni. W tym podejściu przestrzeń staje się unikalną kategorią poznawczą, łączącą sferę materialną, kontekstową i wirtualną działalności przedsiębiorstw.

W zagranicznej literaturze badania nad przestrzenią organizacji w kontekście nauk o zarządzaniu nie są bardziej „popularne”21. Dokonując analizy literatury polskiej i zagranicznej, głównie angielsko- i francuskojęzycznej, oraz czyniąc pewne uproszczenia, można wskazać, iż przestrzeń, po pierwsze, bardzo rzadko jest docelowym przedmiotem badań, a po drugie można stwierdzić, iż badania nad przestrzenią skupiają się wokół następujących dyscyplin czy obszarów wiedzy: socjologii organizacji ${ }^{22}$, facility management ${ }^{23}$, zarządzania wiedzą i innowacjami24, international management ${ }^{25}$, globalnych łańcuchów wartości, geografii organizacji ${ }^{26}$.

Wydaje się, iż w doniesieniach krajowej i zagranicznej literatury naukowej nie jest łatwo znaleźć badania nad przestrzenią organizacji podobne do prezentowanych w niniejszym opracowaniu. Najczęściej badania nad przestrzenią skupiają się na wybranych aspektach lub przejawach przestrzenności, nie dążąc do holistycznego, modelowego ujęcia przestrzeni. Trudność polega nie tylko na konieczności przeprowadzenia bardzo rozległych interdyscyplinarnych badań, ale również, a może przede wszystkim, na konieczności uwzględnienia różnych sposobów istnienia przestrzeni, czyli różnych ich ontologii. Stwarza to duże wyzwanie dla konstrukcji narzędzi badawczych, procedury badań, a także dla odpowiedniej ich interpretacji.

21 Jak zauważa Hernes w jednym z pierwszych szerokich opracowań poświęconych zagadnieniom przestrzeni w kontekście nauk o organizacji, przestrzeń nie była dotychczas (książka została opublikowana w roku 2004) przedmiotem systematycznych badań naukowych w związku z funkcjonowaniem organizacji - por. T. Hernes, Spatial Construction of Organization, John Benjamins, Amsterdam, 2004. Taylor i Spicer zauważają, że w badaniach nad zagadnieniami przestrzeni dominują podejścia fragmentaryczne. Wyraźnie widoczny jest brak kompleksowych opracowań na ten temat, gdyż badania nad przestrzenią w naukach o organizacji i zarządzaniu są trudne do agregowania - zob. S. Taylor, A. Spicer, Time for space: A narrative review of research on organizational spaces, „International Journal of Management Reviews" 2007, no. 9, s. 325-346.

22 Na przykład S. Halford, Towards a Sociology of Organizational Space, „Sociological Research Online" 2009, vol. 9, no. 1.

23 Na przykład C. Beard, I. Price, Space, conversations and place: lessons and questions from organisational development, „International Journal of Facility Management” 2010, vol. 1(2).

24 Na przykład D. Andriessen, Making Sense of Intellectual Capital, Elsevier, New York 2001.

25 Na przykład H. Yeung, Organizational space: a new frontier in international business strategy?, „Critical Perspectives on International Business” 2005, vol. 1, no. 4, s. 219-240.

26 Na przykład M. Müller, Organization Geography, [w:] J.D. Wright (red.), International Encyclopedia of the Social \& Behavioral Sciences, Elsevier, Oxford 2015. 


\section{Podsumowanie}

Wyniki badań umożliwią weryfikację modelu teoretycznego i stwarzają przesłanki do budowy modelu a posteriori. Wymaga to kontynuacji badań, których wyniki, wraz ze zweryfikowaną propozycją modelu przestrzeni, zostaną przedstawione $\mathrm{w}$ kolejnych doniesieniach. Jednocześnie wydaje się, iż można wyrazić przekonanie, że zagadnienie przestrzeni ma duży potencjał badawczy. Perspektywa przestrzenna może być stosowana w wielu badaniach nad zagadnieniami funkcjonowania organizacji i procesami zarządzania, takimi jak na przykład modele biznesu, modele e-biznesu, zagadnienia związane z Przemysłem 4.0, zmiana czy ewolucja ról menedżerów w organizacjach, problematyka globalnych sieci produkcyjnych, zagadnienia „przestrzennej” odpowiedzialności biznesu, czy też - co wydaje się najbardziej oczywiste w świetle wyników badań, w kontekście efektywnego zarządzania środowiskiem pracy. Autor ma świadomość, iż zastosowane podejście badawcze nie wyczerpuje zagadnienia, ale jednocześnie wyraża przekonanie, że niniejsze opracowanie może stanowić przyczynek do naukowej dyskusji o przestrzeni na polu dyscypliny nauki o zarządzaniu.

Bibliografia

Andriessen D., Making Sense of Intellectual Capital, Elsevier, New York 2001.

Beard C., Price I., Space, conversations and place: lessons and questions from organisational development, „International Journal of Facility Management” 2010, vol. 1(2), s. 535-563.

Bojar E., Olesiński Z., The emergence and development of clusters in Poland, Wydawnictwo Difin, Warszawa 2007.

Brzózka J., Jelonek D., Koncepcja pomiaru wartości tworzonej przez aplikacje modeli biznesu: podstawy teoretyczne i studium przypadku, „Przegląd Organizacji” 2015, nr 9, s. 49-55.

Cyfert S., Granice organizacji, Wydawnictwo Uniwersytetu Ekonomicznego w Poznaniu, Poznań 2012.

Cyfert S., Mechanizmy zarzq̨dzania granicami - propozycja teoretycznego ujęcia i wyniki badań empirycznych, „Współczesne Zarządzanie” 2012, nr 3, s. 17-24.

Czakon W., Hipoteza bliskości, „Przegląd Organizacji” 2010, nr 9, s. 16-20.

Czakon W., Sieci w zarzq̨dzaniu strategicznym, Wolters Kluwer Polska, Warszawa 2012.

Czerniawski J., Czasoprzestrzeń Leibniza w fizyce nierelatywistycznej i w teorii względności, „Przegląd Filozoficzny" 2017, t. 26, nr 1, s. 33-52.

Gierszewska G., Romanowska M., Analiza strategiczna przedsiębiorstwa, Polskie Wydawnictwo Ekonomiczne, Warszawa 1994.

Gierszewska G., Wawrzyniak B., Globalizacja, wyzwania dla zarzqdzania strategicznego, Poltext, Warszawa 2001.

Gorynia M., Jankowska B., Klastry a międzynarodowa konkurencyjność i internacjonalizacja przedsiębiorstwa, Wydawnictwo Difin, Warszawa 2008.

Halford S., Towards a Sociology of Organizational Space, „Sociological Research Online” 2009, vol. 9 , no. 1. 
Hernes T., Spatial Construction of Organization, John Benjamins, Amsterdam 2004.

Knop L., Stachowicz J., Krannich M., Olko S., Modele zarzq̨dzania klastrami. Wybrane przykłady, Wydawnictwo Politechniki Śląskiej, Gliwice 2013.

Koźmiński A., Zarzq̨dzanie międzynarodowe, Polskie Wydawnictwo Ekonomiczne, Warszawa 1999.

Müller M., Organization Geography, [w] J.D. Wright (red.), International Encyclopedia of the Social \& Behavioral Sciences, Elsevier, Oxford 2015.

Newton I., Matematyczne zasady filozofii przyrody, Copernicus Center Press, Kraków 2011.

Nogalski B., Kultura organizacyjna. Duch organizacji, Oficyna Wydawnicza Ośrodka Postępu Organizacyjnego, Bydgoszcz 1998.

Pachura P., O przestrzeni w zarządzaniu. Studium metodologiczne, Wydawnictwo Naukowe PWN, Warszawa 2016.

Perechuda K., Dyfuzja wiedzy w przedsiębiorstwie sieciowym. Wizualizacja i kompozycja, Wydawnictwo Akademii Ekonomicznej, Wroctaw 2005.

Perechuda K., Filozofia pustki, struktury - symulakry. Rozważania w kontekście koncepcji Profesora Adama Stabryły, [w:] H. Bieniok(red.), Współczesne kierunki rozwoju nauk o zarządzaniu w kontekście dokonań naukowych Profesora Adama Stabryły, Mfiles.pl, Kraków, 2014, s. $45-52$.

Romanowska M., Alianse strategiczne przedsiębiorstw, Polskie Wydawnictwo Ekonomiczne, Warszawa 1997.

Romanowska R., Granice organizacji, [w:] M. Romanowska, J. Cygler (red.), Granice zarzq̨dzania, Oficyna Wydawnicza SGH - Szkoła Główna Handlowa w Warszawie, Warszawa 2014, s. 89-97.

Sutkowski Ł., Procesy kulturowe w organizacjach, Towarzystwo Naukowe Organizacji i Kierownictwa „Dom Organizatora”, Toruń 2002.

Taylor S., Spicer A., Time for space: A narrative review of research on organizational spaces, „International Journal of Management Reviews" 2007, no. 9, s. 325-346.

Weber A., The Theory of the Location of Industries, Chicago University Press, Chicago 1929.

Wielki J., Analiza rozwoju modeli biznesowych opartych na wykorzystaniu Internetu, „Problemy Zarządzania. Zeszyt Specjalny” 2011, s. 67-82.

Yeung H., Organizational space: a new frontier in international business strategy?, „Critical Perspectives on International Business" 2005, vol. 1, no. 4, s. 219-240.

Yip S., Strategia globalna, Polskie Wydawnictwo Ekonomiczne, Warszawa 2004.

Zaorska A., Ku globalizacji? Przemiany w korporacjach transnarodowych i w gospodarce światowej, Wydawnictwo Naukowe PWN, Warszawa 1998. 


\section{Streszczenie}

Celem opracowania jest przedstawienie wstępnych wyników badań w zakresie empirycznej weryfikacji modelu teoretycznego dotyczącego przestrzeni w kontekście funkcjonowania organizacji. Przyjęto założenie o uznaniu przestrzeni za interesującą kategorię poznawczą w procesach interpretacji i analizy współczesnych organizacji. Jednocześnie wydaje się, że zagadnienie to nie stanowi popularnego obiektu badań wśród badaczy organizacji i procesów zarządzania. Zastosowana metodyka badawcza obejmowała: studia konceptualne nad modelem teoretycznym przestrzeni (model a priori), badania eksperckie, techniki ilościowe oraz jakościowe. W tekście zaprezentowano założenia modelu teoretycznego przestrzeni oraz przedstawiono cząstkowe rezultaty badań ilościowych przeprowadzonych wśród kadry menedżerskiej. Wstępne wyniki badań wskazują na możliwość zaproponowania empirycznie zweryfikowanego modelu przestrzeni.

Słowa kluczowe: organizacja, przestrzeń, model, weryfikacja empiryczna

Research on organisational spaces

\section{Abstract}

The aim of the study is to present the results of research in the field of verification of the theoretical model of space in the context of the functioning of the organization. Space has been recognized as an important cognitive category in the processes of interpreting the behavior of contemporary organizations, and at the same time this issue seems not very popular among researchers of organizations and management processes. Research methodology included: conceptual studies on the theoretical model of space (a priori model), expert studies, quantitative and qualitative techniques. The results of the research indicate that it is possible to propose an empirically verified model of space.

Keywords: organization, space, model, empirical verification 